\title{
ROOT GROWTH BENEATH SIDEWALKS NEAR TREES OF FOUR GENERA
}

\section{by Nicholas E. D’Amato', T. Davis Sydnor ${ }^{2}$, Robin Hunt ${ }^{3}$, and Bert Bishop ${ }^{4}$}

\begin{abstract}
Four genera of trees from four different plant families located in Cincinnati, Ohio, U.S., were examined: Gleditsia (honeylocust), Koelreuteria (goldenraintree), Quercus (oak), and Zelkova (zelkova). The trees were planted in tree lawns $3.5 \mathrm{~m}(11.5 \mathrm{ft})$ or less in tree lawn width. Approximately 1,100 sidewalk joints near the trees planted within the last 20 years were observed for the presence of a root. The incidence of one or more roots, $1 \mathrm{~cm} \mathrm{(3/8} \mathrm{in.)} \mathrm{in} \mathrm{diam-}$ eter or larger growing under the sidewalk at sidewalk joints

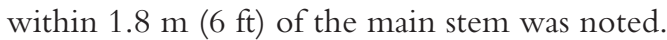

The probability of finding a root growing underneath the sidewalk was modeled against the time since the tree was planted, trunk diameter, and tree lawn width. It was noted that the probability of finding a root approached $100 \%$ as trunk diameter approached $30 \mathrm{~cm}$ (12 in.), with some variation among genera. Gleditsia developed roots growing beneath the sidewalk at the smallest trunk diameter, followed by Zelkova, Koelrenteria, and Quercus. Time since planting and tree lawn width were less significant predictors of root presence than trunk diameter. Overall, Quercus produced the fewest roots of the four genera that were detected beneath the sidewalk.
\end{abstract}

Key Words. Gleditsia; Koelreuteria; Quercus; Zelkova; root growth; tree lawn; trunk diameter; sidewalk damage.

Research has demonstrated that different species of trees can produce root systems of substantially different size over time (Schroth 1995; Costello et al. 1997). Peper (1998) observed that some tree species are associated with damage to sidewalks within shorter time periods after planting than others. One method currently used by cities to reduce the damage from tree roots is the application of root barriers (Barker 1995a, 1995b; McPherson 2000; Costello et al. 1997). When root barriers are used, roots eventually grow beneath the barrier (Barker 1995a, 1995b; Barker and Peper 1995; Peper 1998) and thus barriers might be expected to delay but not eliminate the damage.

Sandfort (2000) had empirically observed differences in performance by some of the trees that they were using in Cincinnati, Ohio, U.S. It was decided to examine some of the common trees planted in the city to seek trends associated with different rates of tree root growth. If root pruning and installation of root barriers could be delayed, it might be possible to "buy time" in the effort to reduce tree-related sidewalk failures. Delaying preventive measures would allow the city to spread the tree installation costs out over time and would also allow the city to prioritize preventive maintenance so the trees that posed the greatest likelihood of interfering with the sidewalk could be addressed first.

\section{MATERIALS AND METHODS}

Trees were selected for the study based on genera, frequency and date of planting, and number planted, as well as previous experience in use. Data were obtained from City of Cincinnati planting records. Trees from four plant families were selected for the study: Gleditsia triacanthos, in the family Fabaceae; Quercus species in the red oak group (Q. rubra, Q. palustris, Q. shumardii, Q. phellos, Q. acutissima, Q. imbricaria, and Q. nigra) in the Fagacea; Zelkova serrata in the Ulmaceae; and Koelreuteria paniculata in the Sapindaceae.

Initial considerations for determining which species to study were trees that were planted between 1981 and 1997 and genera with a sample population of at least 100 trees. The trees selected are inclusive of the entire population of the trees and sites in Cincinnati that met these criteria and were known to the City of Cincinnati Park Board to have been planted at a specified time. Quercus is the only genus for which observations were made on multiple species. This approach was necessary because Quercus is a large genus and multiple species in this genus have been planted on the streets in Cincinnati. No single species was available in sufficient quantities for this study. Species of Quercus were limited to the red oak group because the species listed have similar uses in urban situations (Sydnor and Cowen 2001). The City of 
Cincinnati has regularly planted sufficient numbers of a single species from each of the other three genera for study. Observations were made during the summers of 1999 and 2000.

The following data were recorded for each tree for this analysis: name of the street and approximate address of the tree's location; year planted; width of tree lawn; presence or absence of a root greater than $1 \mathrm{~cm}(3 / 8$ in.) in diameter within $20 \mathrm{~cm}$ (8 in.) of the surface that was growing beneath the sidewalk at joints within 1.8 $\mathrm{m}(6 \mathrm{ft}$.) of the tree; and diameter of main stem at $1.4 \mathrm{~m}$ $(4.5 \mathrm{ft})$ above the ground (dbh). All trees are assumed to have been planted at approximately 4 to $6 \mathrm{~cm}(1.5$ to 2.5 in.) dbh, because that is the size normally purchased by Cincinnati for planting on city streets.

For the purpose of this article, the term "sidewalk joint" refers to one of the predesigned failure points in the sidewalk or an expansion joint. A nursery spade was used to dig to a depth of approximately 20 to 25 $\mathrm{cm}$ (8 to 10 in.) immediately adjacent to the joint on the tree lawn side of the sidewalk. The presence or absence of a root at least $1 \mathrm{~cm} \mathrm{(3/8} \mathrm{in.)} \mathrm{in} \mathrm{diameter}$ growing underneath the walk was noted. The width of the area (i.e., the "sample hole") observed for a root was approximately $25 \mathrm{~cm}$ wide with the joint located approximately in the center. The data reflect roots within approximately $12 \mathrm{~cm}$ (5 in.) of the joint. The data were binary, so if one or more roots were observed in this area it was recorded as "true" for the presence of a root or "false" for the absence of roots.

The dbh of each tree was measured. The date of planting and size of the tree at planting were determined using Cincinnati planting records and the assistance of employees from the Cincinnati Park Board. Tree lawn widths in this study were selected to be smaller than $3.5 \mathrm{~m}(11.5 \mathrm{ft})$ in width. Research has shown that under normal conditions, tree roots will grow at a rate of 30 to $70 \mathrm{~cm}$ (12 to 27 in.) per year (Watson and Himelick 1982; Watson 1985). Taking into account root growth rates and standard root ball sizes for 5-cm (2-in.) trees, three years was assumed to be sufficient time for tree roots to begin to outgrow the tree lawns selected for study.

The probability of finding a $1 \mathrm{~cm}$ or larger root at a sidewalk joint within $1.8 \mathrm{~m}(6 \mathrm{ft})$ of a tree at a given $\mathrm{dbh}$ (in inches) was calculated and modeled using linear regression analyses. Similar models were also made on the mean probability of finding a root at given number of years from planting and at a given tree lawn width (in meters). Means from the models were used because the models are intended to apply collectively to groups of trees of a given age or dbh class rather than to an individual tree chosen at random. Binary logistic regression was used to compare the relative incidences of positive root probes among genera for trees planted between 5 and 13 years previously.

\section{RESULTS AND DISCUSSION DBH vs. Probability of a Root}

Approximately 1,100 joints next to trees were examined, with an average of 281 per genus (Table 1). Regression models were performed on data on root presence at joints next to trees ranging from the lowest diameter in the study, the 2.5- to 5-cm (1- to 2-in.) class, to the diameter where the probability of a $1 \mathrm{~cm}$ or larger root underneath a joint became 100\%. Root presence at the sidewalk joints in this study reached 100\% when the trees reached a dbh of 27 to $35 \mathrm{~cm}$ (11 to 14 in.). The dbh ranged from about $27 \mathrm{~cm}$ for most genera to about $35 \mathrm{~cm}$ for Quercus. While Koelreuteria also approached 100\% root presence at $27 \mathrm{~cm}$, the sample pool did not include sufficient numbers of trees above $27 \mathrm{~cm}$ to confirm a strong pattern for that genus (Figure 1).

Table 1. Summary data for four genera of trees detailing mean tree lawn size, mean time from planting, and number joints observed.

\begin{tabular}{|c|c|c|c|}
\hline Genus & $\begin{array}{l}\text { Mean tree } \\
\text { lawn size } \\
\text { meters (ft) }\end{array}$ & $\begin{array}{l}\text { Mean time } \\
\text { since planting } \\
\text { (years) }\end{array}$ & $\begin{array}{l}\text { Number of } \\
\text { joints } \\
\text { observed }\end{array}$ \\
\hline Gleditsia & $1.6(5.3)$ & 11.0 & 282 \\
\hline Koelreuteria & $1.4(4.6)$ & 10.6 & 234 \\
\hline Quercus & $2.3(7.4)$ & 9.8 & 384 \\
\hline Zelkova & $2.1(6.8)$ & 9.0 & 225 \\
\hline \multicolumn{4}{|l|}{ All } \\
\hline Total & - & - & 1125 \\
\hline Mean & $2.0(6.5)$ & 10.1 & 281 \\
\hline Median & $1.9(6.2)$ & 9.0 & - \\
\hline Std. dev. & $0.5(1.8)$ & 3.7 & - \\
\hline
\end{tabular}

When the probability of a root was modeled against the dbh of the tree, all models indicated that diameter class (inches) was a significant predictor $(P<$ 0.05 ) of root presence under the sidewalk (Figure 1). Gleditsia and Koelrenteria had $\mathrm{r}^{2}$ values of $89 \%$ and $61 \%$, respectively, while Quercus and Zelkova had $\mathrm{r}^{2}$ values of $30 \%$ and 50\%, respectively (Table 2). Quercus showed the weakest relationship between diameter and root 
a. Probability of a root as predicted by dbh for all genera $\left(r^{2}=75.5 \%\right)$ :

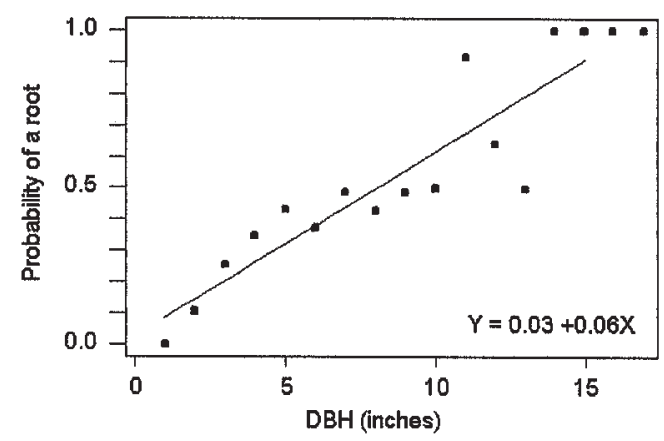

c. Probability of a root as predicted dbh for Koelreuteria $\left(r^{2}=61.1 \%\right)$

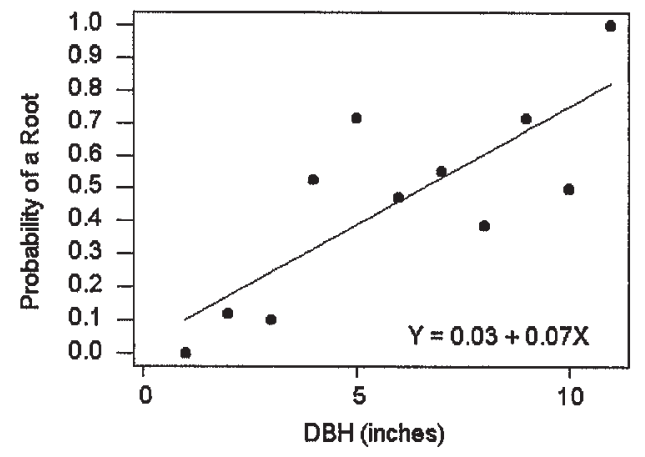

b. Probability of a root as predicted by dbh for Gleditsia $\left(r^{2}=88.7 \%\right)$

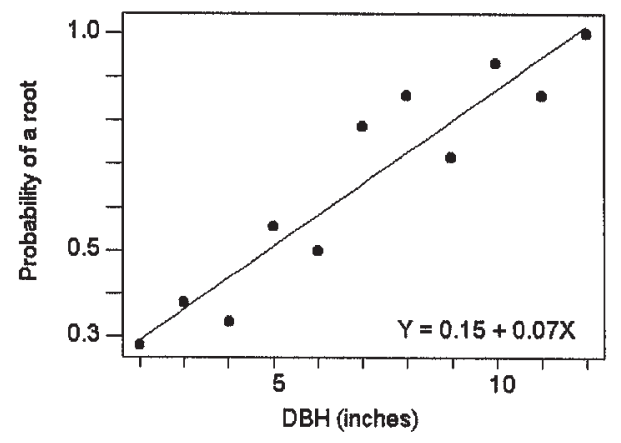

d. Probability of a root as predicted by by dbh for Quercus $\left(r^{2}=30.2 \%\right)$

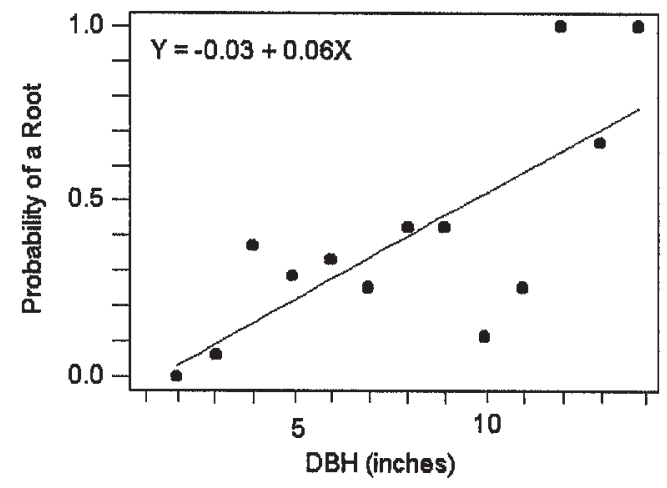

e. Probability of a root as predicted by dbh for Zelkova $\left(\mathrm{r}^{2}=49.6 \%\right)$

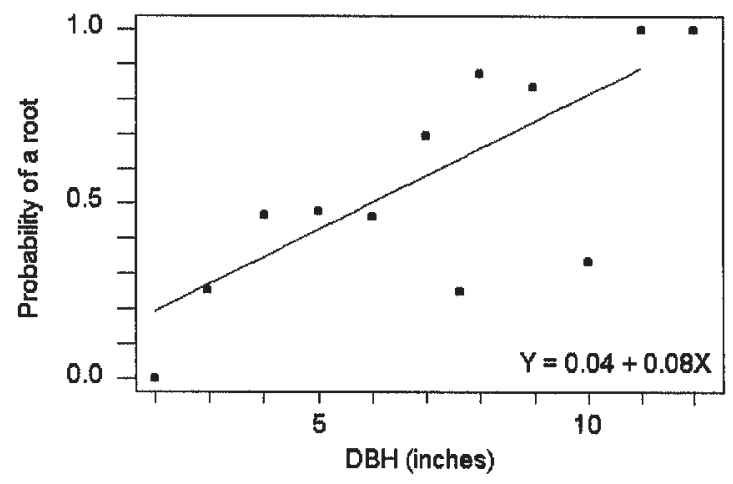

Figure 1. Probability of finding a root greater than $1 \mathrm{~cm}$ at a sidewalk joint within $1.8 \mathrm{~m}$ of a tree planted in a tree lawn less than $3.5 \mathrm{~m}$ in width. All analyses are significant at the $95 \%(P=0.05)$ level or greater. 
probability, which may be due to several factors: Quercus was the only genus for which multiple species were represented, it was planted in the widest tree lawns, and it produced fewer positive root probes on average compared with the other three genera as shown in Table 3. When the dbh was modeled for all of the joints and all genera in the study, the $\mathrm{r}^{2}$ was $75 \%$ with $P<0.001$. It is also interesting to note that the slopes of the regression lines for the various genera were fairly consistent between 0.06 and 0.08. Data on Quercus and Gleditsia are comparable to Gilman (1988), who showed that trunk diameter was a reasonable predictor of root radius. Gilman noted that the $\mathrm{r}^{2}$ for $\mathrm{dbh}$ as a predictor of root radius for Gleditsia triacanthos was 0.79 and for Quercus virginiana was 0.41 .

\section{Time Since Planting vs. Probability of a Root}

The average time since planting of the trees in the study was 10.1 years (Table 1). Figure 2 shows the models generated for the probability of finding a

Table 2. Simple linear regression $\mathbf{r}^{2}$ values for the probability of roots at sidewalk joints within $1.8 \mathrm{~m}$ $(6 \mathrm{ft})$ of tree as predicted by time since planting and trunk diameter.

\begin{tabular}{|c|c|c|c|c|}
\hline Genus & $\begin{array}{l}\text { Adjusted } r^{2} \\
(\mathrm{dbh})\end{array}$ & $\begin{array}{l}\text { Adjusted } r^{2} \\
\text { (time) }\end{array}$ & $\begin{array}{l}P \text {-value } \\
\text { dbh as a } \\
\text { predictor of } \\
\text { root problem }\end{array}$ & $\begin{array}{l}P \text {-value } \\
\text { time as a } \\
\text { predictor or } \\
\text { root problem }\end{array}$ \\
\hline Gleditsia & $88.7 \%$ & $80.0 \%$ & $<0.01$ & $0.10^{*}$ \\
\hline Koelreuteria & $61.1 \%$ & $44.9 \%$ & $<0.01$ & $0.06^{*}$ \\
\hline Quercus & $30.2 \%$ & $38.1 \%$ & 0.03 & 0.02 \\
\hline Zelkova & $49.6 \%$ & $54.1 \%$ & 0.02 & $0.06^{*}$ \\
\hline All trees & $75.5 \%$ & $62.1 \%$ & $<0.01$ & $<0.01$ \\
\hline
\end{tabular}

*Denotes model that is not significant at the $95 \%$ level.

Table 3. Differences in root incidence at sidewalk joints within $1.8 \mathrm{~m}$ of trees of four genera. The percentage of positive root probes, years since planting, number of joints observed and $P$-values for differences among genera.

\begin{tabular}{llllrrrr}
\hline & $\begin{array}{l}\text { Positive } \\
\text { root } \\
\text { probes }\end{array}$ & $\begin{array}{l}\text { Years } \\
\text { since }\end{array}$ & $\begin{array}{l}\text { Number of } \\
\text { raw } \%\end{array}$ & \multicolumn{2}{c}{ P-values for differences (binary regression) } \\
\cline { 5 - 8 } & planting & observations & Gleditsia & Zelkova & Koelreuteria & Quercus \\
\hline Gleditsia & 83 & $5-12$ & 212 & - & 0.092 & 0.065 & $<0.001$ \\
Zelkova & 60 & $6-12^{*}$ & 197 & 0.092 & - & 0.806 & $<0.001$ \\
Koelreuteria & 55 & $5-12$ & 162 & 0.065 & 0.806 & - & $<0.001$ \\
Quercus & 27 & $5-13^{*}$ & 347 & $<0.001$ & $<0.001$ & $<0.001$ & - \\
\hline
\end{tabular}

"Observations not available for Zelkova at year 5 and Quercus at year 12. root as predicted by time. Time proved to be a less reliable predictor of root presence than dbh. For some genera, tree ages were not as well distributed as diameters. This finding suggests that differences in site conditions played a role in tree growth. When root probability was modeled using time (years) as a predictor, only Quercus demonstrated statistical significance at $\alpha=0.05$. Except for Quercus, $P$-values for the time models were lower than in the dbh models (Figure 2). Table 2 shows that $r^{2}$ values for the time models were notably lower for Gleditsia and Koelreuteria and for "all genera" relative to the dbh models. The $r^{2}$ for Quercus was slightly higher for the time model than for the dbh model, but oaks still had an $\mathrm{r}^{2}$ below 50\%. The $\mathrm{r}^{2}$ for the Zelkova time model did not change substantially from the dbh model and remained near 50\%. As was the case with diameter, Gleditsia appeared to form roots the earliest, with Zelkova the next earliest, followed by Quercus and Koelreuteria. However, the differences among the genera for the time models may be attributable to sample variation. The slopes of the regression lines for the various genera in the time models were more variable than in the dbh models, varying between 0.03 and 0.07 .

\section{Tree Lawn Width vs. Probability of a Root}

Previous data have suggested that the distance between the tree and the sidewalk (as might be influenced by tree lawn width) does have some effect on tree-related sidewalk failure (Francis et al. 1996). Holding dbh relatively constant, root probability at 407 joints was modeled using tree lawn width as a predictor. Trees were selected in from the center of the range of diameter classes used in the study, specifically the 15 to $20 \mathrm{~cm}$ (6 to 8 in.) diameter classes. Tree lawn widths in this model ranged from less than $1 \mathrm{~m}$ to $3 \mathrm{~m}$ with an average width of $2 \mathrm{~m}$ (Table 1). The resulting adjusted $r^{2}$ value for the linear regression model was $0.0 \%$. When weighted regression was used to account for variations in sample size at the different tree lawn width levels, the resulting adjusted $r^{2}$ value for the model was $30.8 \%$ and significance was low 
a. Probability of a root as predicted by time for all genera $\left(r^{2}=62.1 \%\right)$

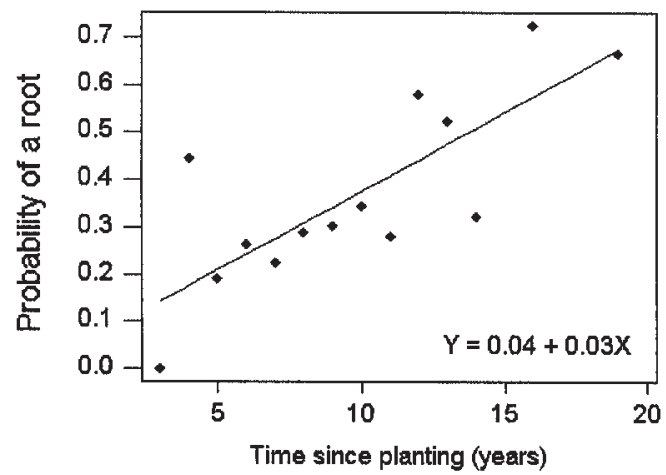

c. Probability of a root as predicted by time for Koelreuteria $\left(\mathrm{r}^{2}=44.9 \% *\right)$

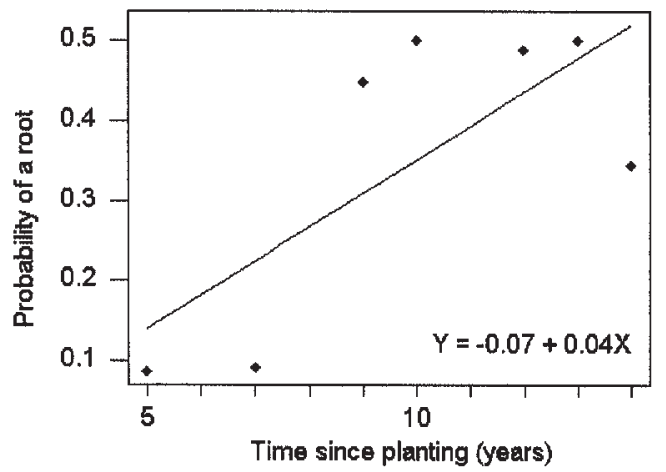

e. Probability of a root as predicted by time for Zelkova $\left(r^{2}=54.1 \%{ }^{*}\right)$

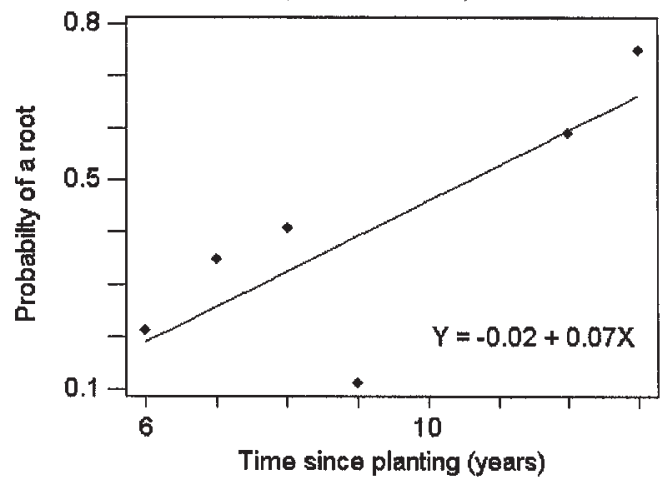

b. Probability of a root as predicted by time for Gleditsia $\left(\mathrm{r}^{2}=80.0 \% *\right)$

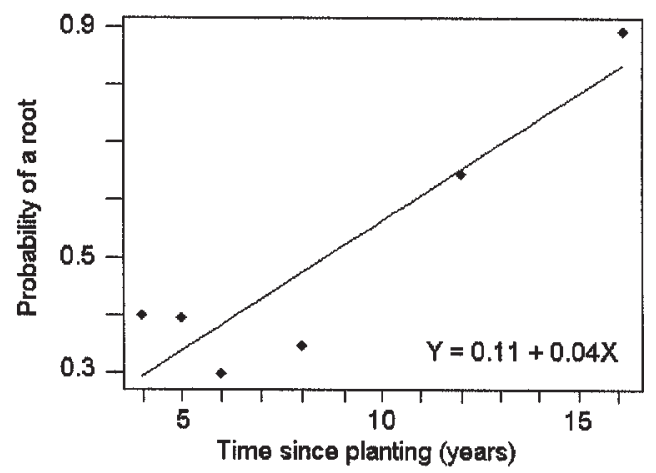

d. Probability of a root as predicted by time for Quercus $\left(r^{2}=38.1 \%\right)$

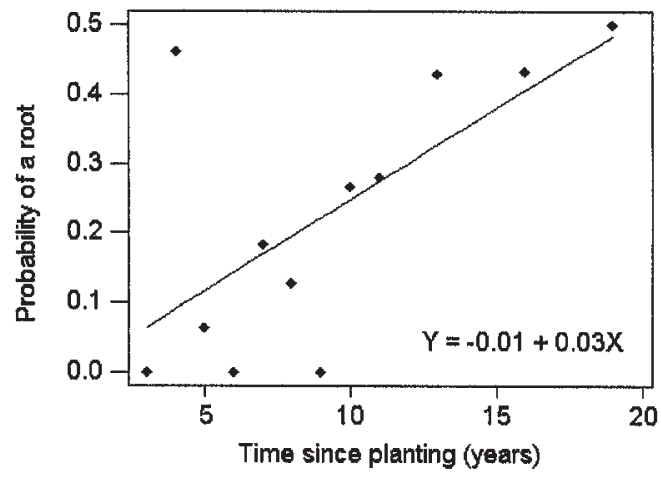

* Indicates that the model is not significant at the $95 \%$ level.

Figure 2. Probability of finding a root greater than or equal to $1 \mathrm{~cm}$ at a sidewalk joint within $1.8 \mathrm{~m}$ of a tree planted in a tree lawn less than $3.5 \mathrm{~m}$ in width as predicted by years since planting. Analyses are significant at the $95 \%(P=0.05)$ level or greater except where noted. 
with $P=0.15$ (Figure 3). Tree lawn width proved to be a poor predictor of root presence in this model. It is interesting to note, however, that when binary logistic regression was performed on the data, the Hosmer-Lemeshow goodness of fit test was 0.992 with a $P<0.001$. The data appeared to show a fairly linear, inverse relationship until tree lawns reached $3 \mathrm{~m}$ in width. Twentyfour sidewalk joints in tree lawns 3 to $3.5 \mathrm{~m}$ wide showed an unusually high root presence. No explanation was apparent that explained the deviation; however, the number of joints in this range was low enough that it did not adversely affect the HosmerLemeshow goodness of fit test for the binary regression model.

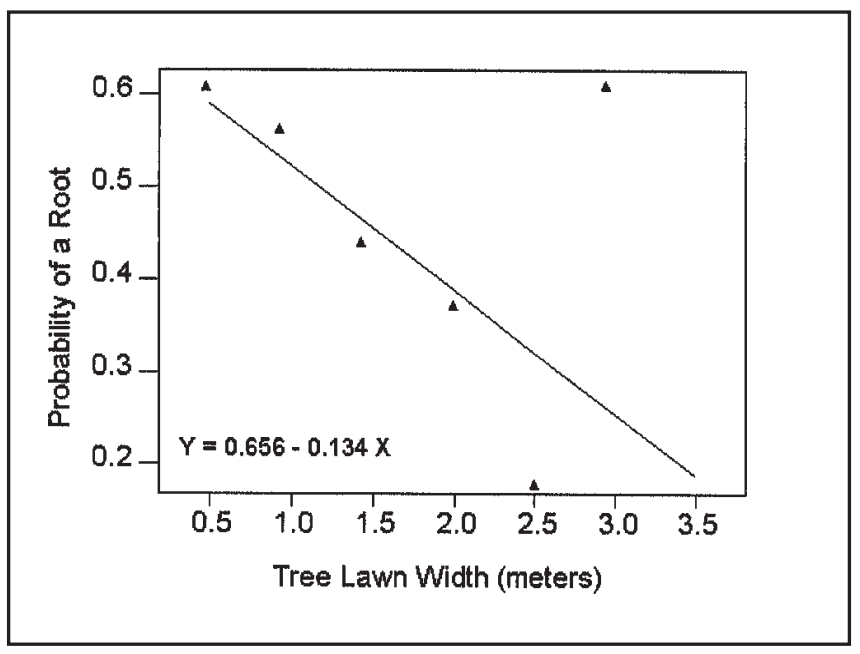

Figure 3. Probability of a root as predicted by tree lawn width for 15- to $20-\mathrm{cm}$ dbh class trees. Weighted linear regression analysis $\left(r^{2}=30.8 \%\right)$. Linear regression not significant at $\alpha=0.05$. Binary logistic regression showed a Hosmer-Lemeshow goodness of fit of 0.992 with $P<0.001$. The binary regression equation is $Y=0.654-0.280 X$.

\section{Differences Among Genera}

Binary logistic regression was used to compare the relative incidences of positive root probes among genera for trees planted roughly 5 to 12 years previously (Table 3). Only oak showed significant differences in root presence from the other genera $(\alpha=0.05)$. Oak had on average the fewest positive root probes of the three. Marginal difference was shown between Gleditsia and Koelreuteria $(\alpha=0.065)$, with Koelrenteria producing fewer positive root probes. No data were available on Quercus planted 12 years earlier or on Zelkova planted 5 years earlier. As a result, comparisons reflect data on Quercus 5 to 13 years since planting and for Zelkova 6 to 12 years after planting.

\section{Practical Applications}

These data suggest that root presence beneath sidewalk

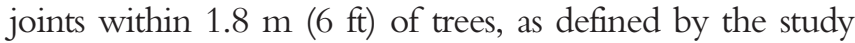
criteria, approaches $100 \%$ as trees approach 25 to $30 \mathrm{~cm}$ (10 to 12 in.) in diameter. Data for all genera show that the probability of finding roots begins to exceed $50 \%$ between 10 and $25 \mathrm{~cm}$ (5 and 10 in.) dbh. Preventive maintenance might be planned to target trees before they reach a consistent $25-\mathrm{cm}$ diameter. Probability of roots for Gleditsia and Zelkova begins to exceed 50\% shortly after the trees reach 13 to $20 \mathrm{~cm}$ (5 to 8 in.) in diameter. Quercus and Koelreuteria were less aggressive than Gleditsia and Zelkova. Quercus appeared to be the least aggressive of the four genera (Table 3). Recall that the trees in this study were all planted at approximately $5 \mathrm{~cm}$ (2 in.) dbh. Neither the diameter nor time models demonstrate significant differences among genera that exceeded sample variation. Sample variation may be attributable to the different species of trees producing roots of different diameters and differences in site conditions that might affect the rate of root development over time.

Previous research in Cincinnati (D'Amato et al. 2002) suggests that the condition of the adjacent sidewalk may also determine the likelihood of finding roots under a sidewalk during the first 20 years after planting. That study shows that cracked sidewalks are more likely to favor oxygen dissemination into the soil under the sidewalk and are associated with increased root growth. That knowledge, when combined with the data from this study, suggests that aggressively rooted species planted in older cracked sidewalks would require the earliest intervention to delay sidewalk failure related to tree root growth. Conversely, less aggressively rooted species planted near newer or well-constructed sidewalks with few cracks allow for a delay in preventive measures such as root pruning or root barrier installation.

The City of Cincinnati expects sidewalks to have a service life of 20 to 25 years (Sandfort 2000). Previous research in Cincinnati (Sydnor et al. 2000) found that the incidence of tree-related sidewalk failure during the first 20 years was fairly low. Preventive measures for less aggressive species such as oak may not be cost effective if trees are planted near well-constructed, intact, or new sidewalks and the goal is to prevent tree-related failure during the intended 20- to 25-year service life of the sidewalk. 
Urban foresters must ultimately use their experience with the species of trees that they are planting, along with knowledge of the sidewalk conditions and construction techniques employed to build sidewalks in their area. This information should be used to make decisions such as which tree species would benefit from delayed root barrier installation, which species should be treated early after planting, and which species may not benefit at all from such treatments. The models provided here are intended to assist city foresters in developing guidelines for citywide planning and preventive maintenance aimed at reducing sidewalk damage associated with tree roots. Armed with the information in this report, city foresters will have additional information on which to base a decision.

\section{LITERATURE CITED}

Barker, P.A. 1995a. Managed development of tree roots. I. Ultra-deep rootball and root barrier effects on European hackberry. J. Arboric. 21:203-207.

Barker, Philip A. 1995b. Managed development of tree roots. II. Ultra-deep rootball and root barrier effects on Southwestern black cherry.J. Arboric. 21:251-258.

Barker, P.A., and P.J. Peper. 1995. Strategies to prevent damage to sidewalks by tree roots. Arboric. J. 19:295-309.

Costello, L.R., C.L. Elmore, and S. Steinmaus. 1997. Tree root response to circling root barriers. J. Arboric. 23:211-218.

D'Amato, N., T.D. Sydnor, and B. Bishop. 2002. Which comes first the root or the crack? J. Arboric. 28:277-282.

Gilman, E.F. 1988. Predicting root spread from trunk diameter and branch spread. J. Arboric. 18:85-89.

Francis, J., B. Parresol, and J. De Patino 1996. Probability of damage to sidewalks and curbs by street trees in the tropics. J. Arboric. 22:193-197.

McPherson, E.G. 2000. Expenditures associated with conflicts between street tree root growth and hardscape in California. J.Arboric. 26:289-297.

Peper, P.J. 1998. Comparison of root barriers installed at two depths for reduction of white mulberry roots in the soil surface, pp 82-93. In Watson, G., and D. Neely, D (Eds.). The Landscape Below Ground II: Proceedings of an International Workshop on Tree Root Development in Urban Soils. 1998. San Francisco, CA. International Society of Arboriculture, Champaign, IL.

Sandfort, S. 2000. Urban forester, City of Cincinnati Planning Section, Cincinnati, OH. Personal communication.

Schroth, G. 1995. Tree root characteristics as criteria for species selection and systems design in agroforestry. Agrofor. Syst. 30:125-143.

Sydnor, T.D., and W.F. Cowen. 2001. Ohio Trees. Ohio State University Extension Bulletin 700, Columbus, OH. 212 pp.
Sydnor, T.D., D. Gamstetter, J. Nichols, B. Bishop, J. Favorite, C. Blazer, and L. Turpin. 2000. Trees are not the root of sidewalk problems. J. Arboric. 26:21-29.

Watson, G. 1985. Tree size affects root regeneration and top growth after transplanting. J. Arboric. 11:37-40.

Watson, G.W., and E.B. Himelick. 1982. Root regeneration of transplanted trees. J. Arboric. 8:305-310.

Acknowledgments. This work supported in part by a grant from the National Urban and Community Forestry Council (NUCFAC) and the City of Cincinnati Park Board.

${ }^{1 *}$ Graduate Assistant

${ }^{2}$ Professor of Urban Forestry

School of Natural Resources

The Ohio State University

2021 Coffey Road

Columbus, OH 43210, U.S.

${ }^{3}$ Urban Forest Specialist

Cincinnati Park Board

The City of Cincinnati, Ohio

${ }^{4}$ Statistical Consultant

Ohio Agricultural Research and Development Center

Wooster, OH 44691, U.S.

Résumé. Quatre genres d'arbres appartenant à quatre familles différentes ont été étudiés au sein de la ville de Cincinnati, soient: Gleditsia (févier), Koelreuteria (savonnier), Quercus (chêne), Zelkova (zelkova). Les arbres étaient plantés dans des banquettes de 3,5 m (11,5 pi.) de largeur ou moins. Environ 1100 joints de trottoir près des arbres plantés au cours des 20 dernières années ont été observés en regard de la présence de racines. L'incidence de la présence de chaque racine ayant un diamètre minimum de $1 \mathrm{~cm}(3 / 8$ po. $)$ et qui poussait sous le joint du trottoir à une distance de $1,8 \mathrm{~m}$ (6 pi.) ou moins du tronc a été consigné. La probabilité de trouver une racine croissant sous le trottoir a été modélisée en fonction du temps depuis la plantation de l'arbre, du diamètre du tronc et de la largeur de la banquette. Il a alors été observé que la probabilité de trouver une racine s'approchait de 100\% lorsque le tronc s'approchait des $30 \mathrm{~cm}$ (12 po.) de diamètre, et ce cependant avec certaines variations entre les divers genres. Le Gleditsia était l'espèce qui développait des racines sous le trottoir avec les diamètres de tronc les plus faibles, suivi du Zelkova, du Koelrenteria et du Quercus. La période écoulée depuis la plantation ainsi que la largeur de la banquette étaient de moins bonnes variables de prédiction de la présence de racines que le diamètre du tronc. Globalement, le Quercus produisait le moins de racines sous le trottoir parmi les quatre genres étudiés. 
Zusammenfassung. In Cincinnati, Ohio wurden 4 Baumarten aus 4 verschiedenen Familien untersucht: Gleditsia, Koelreuteria, Quercus und Zelkova. Die Bäume wurden in 3,5 m breiten Baumscheiben gepflanzt. Schätzungsweise 1100 Bürgersteige neben Baumpflanzungen der letzten 10 Jahre wurden auf Wurzelwachstum untersucht. Die Anwesenheit von 1 oder mehreren Wurzeln mit $1 \mathrm{~cm}$ Durchmesser und größer unterhalb des Pflasters und innerhalb eines 1,8 m großen Radius vom Stamm wurde notiert. Die Wahrscheinlichkeit Wurzelwachstum unter dem Bürgersteig zu finden wurde gegenübergestellt mit dem Zeitraum seit der Pflanzung des Stammdurchmessers und der Breite des Baumes. Es wurde festgestellt, dass die Wahrscheinlichkeit anwesender Wurzeln unter dem Pflaster $100 \%$ erreichte, wenn der Baumdurchmesser auf $30 \mathrm{~cm}$ und mehr anstieg, mit geringen Variationen unter den Arten. Gleditsia entwickelte Wurzeln schon bei kleineren Durchmessern, gefolgt von Zelkova, Koelreuteria und Quercus. Der Pflanzzeitpunkt und die Größe der Baumscheibe waren geringere Indikatoren für das Wurzelwachstum als der Stammdurchmesser. Abschließend produzierte Quercus von allen 4 Arten die wenigsten Wurzeln unter Bürgersteigen.
Resumen. Fueron examinados cuatro géneros de árboles de 4 diferentes familias de plantas localizadas en la Ciudad de Cincinnati, Ohio: Gleditsia (honeylocust), Koelrenteria (golden raintree), Quercus (encino) y Zelkova (zelkova). Los árboles se plantaron en áreas pastizadas de 3,5 metros de amplitud. Aproximadamente 1,100 sitios en aceras cerca de los árboles plantados en los últimos 20 años fueron observados para ver la presencia de raíces. Se observó la incidencia de 1 o más raíces, $1 \mathrm{~cm} \mathrm{(3/8} \mathrm{pulg)} \mathrm{en} \mathrm{diámetro,} \mathrm{o}$ mayores, creciendo bajo las aceras dentro de $1.8 \mathrm{~m}$ del tronco principal. Se modeló la probabilidad de encontrar raíces creciendo bajo la acera contra el tiempo desde que el árbol fue plantado, diámetro del tronco y amplitud del área pastizada. Se notó que la probabilidad de encontrar una raíz se aproxima al 100\% a medida que el diámetro del tronco alcanza $30 \mathrm{~cm}$ (12 pulgadas), con alguna variación entre géneros. Gleditsia desarrolló raíces creciendo bajo las aceras en el diámetro del tronco más pequeño, seguido por Zelkova, Koelrenteria y Quercus. El tiempo desde la plantación y el ancho de la pradera fueron factores menos significativos de la presencia de raíces que el diámetro del tronco. Por otra parte, Quercus produjo menos raíces, de los cuatro géneros detectados bajo las aceras. 